\title{
LIDAR NETWORK OBSERVATION OF DUST LAYER EVOLUTION OVER THE GOBI DESERT IN MAY 2013
}

\author{
Kei Kawai ${ }^{1 *}$, Kenji Kai ${ }^{1}$, Yoshitaka Jin ${ }^{2}$, Nobuo Sugimoto ${ }^{2}$, Dashdondog Batdorj ${ }^{3}$ \\ ${ }^{I}$ Nagoya University, Japan, *kawai.kei@e.mbox.nagoya-u.ac.jp \\ ${ }^{2}$ National Institute for Environmental Studies, Japan \\ ${ }^{3}$ National Agency for Meteorology and Environmental Monitoring, Mongolia
}

\begin{abstract}
A lidar network captured the evolution of a dust layer in the Gobi Desert on 22-23 May 2013. The lidar network consists of a ceilometer and two AD-Net lidars in Mongolia. The dust layer was generated by a strong wind due to a cold front and elevated over the surface of the cold front by an updraft of the warm air in the cold-front system. It was evolving from the atmospheric boundary layer to the free troposphere while moving 600 $\mathrm{km}$ through the desert with the cold front.
\end{abstract}

\section{INTRODUCTION}

Asian dust originates in arid and semi-arid regions of East Asia such as the Gobi Desert and the Taklimakan Desert $[1,2]$. A strong wind raises the dust from the ground to the atmospheric boundary layer $(\mathrm{ABL})$, which is the bottom layer of the atmosphere. If the dust reaches the free troposphere (FT) over the ABL, it can be transported over a long range by westerlies $[3,4$, 5]. However, the capping inversion between the $\mathrm{ABL}$ and the FT prevents the dust in the ABL from reaching the FT. The mechanism to elevate the dust from the ABL to the FT is not clear due to little observational evidence.

Some studies have suggested that an updraft of a cold-frontal system elevates dust from the ABL to the FT by using a space-borne lidar and numerical models [6, 7]. Moreover, our previous study has shown this fact by using a ceilometer installed in the central part of the Gobi Desert [8]. In addition to the ceilometer, two AD-Net lidars have been operated in the eastern part of the desert [9]. The ceilometer and the two lidars constitute a lidar network in the desert. The present study takes advantage of the lidar network and reveals the process that the cold-frontal system elevates dust from the ABL to the FT.

\section{OBSERVATIONS AND DATA}

A lidar network in the Gobi Desert consists of a ceilometer and two AD-Net lidars. The ceilometer is installed at Dalanzadgad $\left(43.58^{\circ} \mathrm{N}, 104.42^{\circ} \mathrm{E}\right.$, $1470 \mathrm{~m}$ above sea level (ASL); D in Fig. 1), which is in the central part of the desert. The ADNet lidars are placed at Sainshand $\left(44.87^{\circ} \mathrm{N}\right.$, $110.12^{\circ} \mathrm{E}, 937 \mathrm{~m}$ ASL; $\mathrm{S}$ in Fig. 1) and ZamynUud $\left(43.72^{\circ} \mathrm{N}, 111.90^{\circ} \mathrm{E}, 962 \mathrm{~m} \mathrm{ASL}\right.$; Z in Fig. 1), which are in the eastern part of the desert. The distances among three sites are $480 \mathrm{~km}(\mathrm{D}-\mathrm{S})$, $600 \mathrm{~km}(\mathrm{D}-\mathrm{Z})$, and $190 \mathrm{~km}(\mathrm{~S}-\mathrm{Z})$.

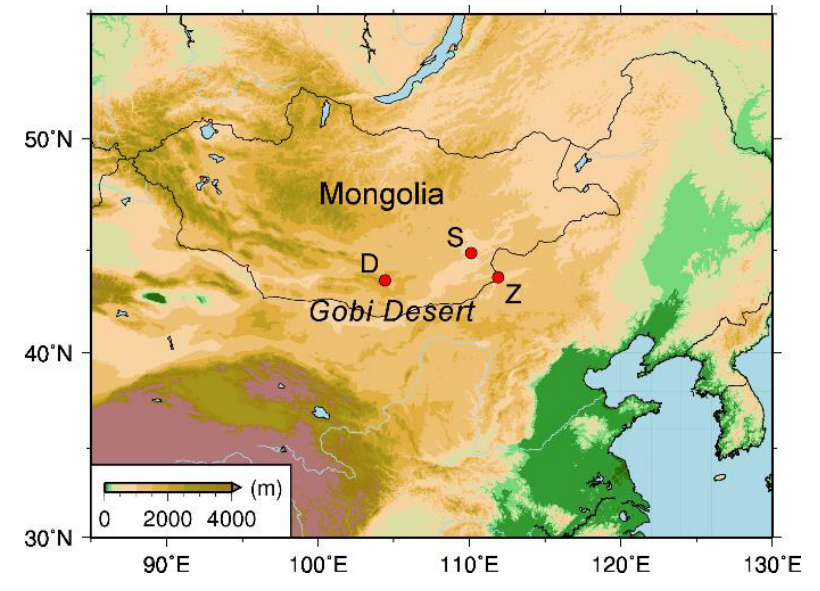

Figure 1 Topographic map around Mongolia. The redfilled circles with the characters of $D, S$, and $Z$ indicate the locations of Dalanzadgad, Sainshand, and ZamynUud, respectively.

The ceilometer at Dalanzadgad is a Vaisala CL51 ceilometer, which employs a diode laser of a 910$\mathrm{nm}$ wavelength as the light source. It outputs a vertical profile of attenuated backscatter coefficient with a height resolution of $10 \mathrm{~m}$ every 6 seconds. The present study used the observation data averaged in 15 minutes and $30 \mathrm{~m}$. The ceilometer was installed in Tsukuba, Japan, before moved to Dalanzadgad and corrected by a dualwavelength lidar [10]. 
AD-Net is a lidar observation network for Asian dust and other aerosols in East Asia [9]. The ADNet lidars at Sainshand and Zamyn-Uud obtain vertical profiles of attenuated backscatter coefficients at wavelengths of $532 \mathrm{~nm}$ and 1064 $\mathrm{nm}$ and volume depolarization ratio at a wavelength of $532 \mathrm{~nm}$. The time and height resolutions of the parameters are 15 minutes and $30 \mathrm{~m}$, respectively.

The present study used surface weather charts produced by Japan Meteorological Agency and surface meteorological data provided from the SYNOP reports. The present weather codes of $06-$ $09,30-35$, and 98 are regarded as dust events which consist of dust storm, floating dust, and blowing dust [11].

\section{RESULTS AND DISCUSSION}

A dust event occurred in the Gobi Desert on 2223 May 2013. Vertical distribution of dust was successfully observed by the lidar network in the desert during the dust event. The local standard time (LST) in Mongolia is 8 hours ahead of the coordinated universal time (UTC).

\subsection{Pressure pattern}

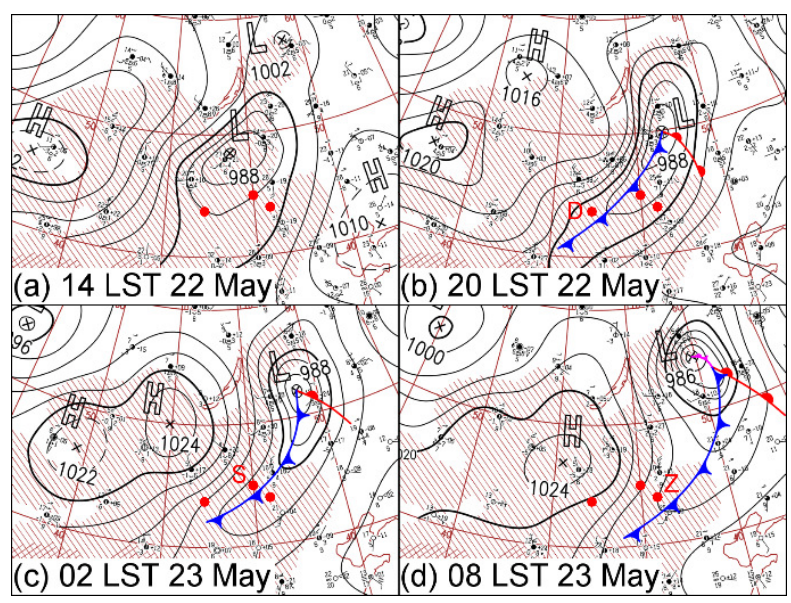

Figure 2 Surface weather charts around Mongolia on 22-23 May 2013 (Japan Meteorological Agency). The red dots with the characters of $D, S$, and $Z$ indicate the locations of Dalanzadgad, Sainshand, and Zamyn-Uud, respectively.

Figure 2 presents surface weather charts around Mongolia on 22-23 May 2013. A low pressure was in northern Mongolia at 14 LST on 22 and moved northeastward until 08 LST on 23 . The low pressure was accompanied with cold and warm fronts from 20 LST on 22. The fronts were generated between 14 LST and 20 LST on 22 . The cold front moved southeastward across the Gobi Desert with a speed of $30 \mathrm{~km} / \mathrm{h}$. It passed Dalanzadgad between 14 LST and 20 LST on 22, Sainshand between 20 LST on 22 and 02 LST on 23, and Zamyn-Uud between 02 LST and 08 LST on 23.

\subsection{Meteorological field}

Figure 3 indicates surface winds and dust phenomena over Mongolia at 20 LST on 22 May 2013. Strong northwest winds were observed in the central part of the Gobi Desert. The wind speed ranged from $6 \mathrm{~m} / \mathrm{s}$ to $16 \mathrm{~m} / \mathrm{s}$. The strong winds were located behind and along the cold front. In addition, dust phenomena were observed in the region of the strong winds. In summary, the dust outbreak during this dust event was caused by the strong winds which were generated by the cold front.

20 LST 22 May 2013

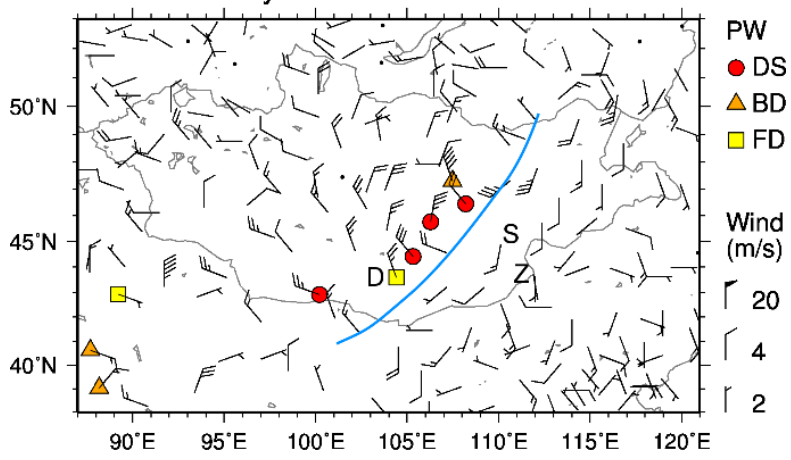

Figure 3 Distribution map of surface wind and present weather at 20 LST on 22 May 2013. The legend of the wind is shown at the lower right of the figure. The redfilled circles, orange-filled triangles, and yellow-filled squares present dust storm (DS), blowing dust (BD), and floating dust (FD), respectively. The characters of

$D, S$, and $Z$ indicate the locations of Dalanzadgad, Sainshand, and Zamyn-Uud, respectively. The blue line indicates the cold front shown in Fig. $2 b$.

\subsection{Dust elevation mechanism}

Figure 4 presents the observation results at Dalanzadgad, Sainshand, and Zamyn-Uud from 14 LST on 22 to 18 LST on 23 in May 2013. At Dalanzadgad, a dust layer is shown by large attenuated backscatter coefficient over the ground between 14 LST on 22 and 02 LST on 23 (Fig. 4a). 
Judging from each vertical profile (not shown), the top height of the dust layer reached $1.8 \mathrm{~km}$ at 20 LST on 22. The dust layer was the densest at 21 LST on 22. During the dust event, the wind speed ranged from $6 \mathrm{~m} / \mathrm{s}$ to $10 \mathrm{~m} / \mathrm{s}$, and the wind direction was between the west and the northwest. This strong wind raised the dust from the ground. The cold front passed between 17 LST and 20 LST on 22 because the wind speed increased though the wind-direction change was not clear. Cold air advected over the ground below a height of $1.8 \mathrm{~km}$ after the cold front passed. The cold air included little dust from 2230 LST on 22. The leading edge of the cold air was not clear because the dust layer extended from the warm air to the cold air. The top of the cold air corresponds to the surface of the cold front. Some dust floated at a height range of $0.8-1.6 \mathrm{~km}$ between 22 LST on 22 and 00 LST on 23. It was located over and along the surface of the cold front. Our previous study has shown that the dust was elevated by an updraft of the warm air in the cold-frontal system [8].

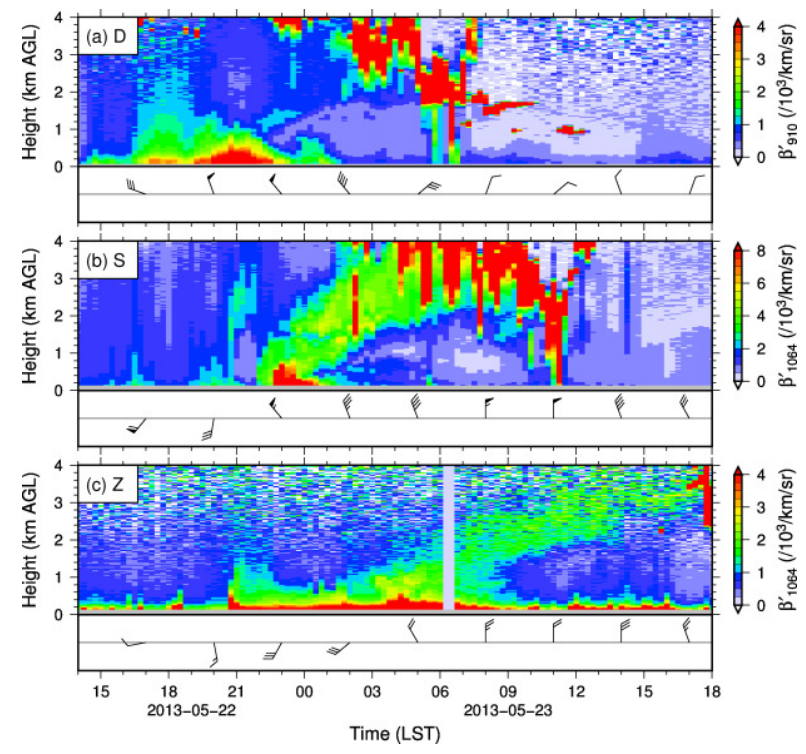

Figure 4 Time-height cross sections of attenuated backscatter coefficient (each upper) and time series of surface wind (each lower) on 22-23 May 2013 at (a) Dalanzadgad (D), (b) Sainshand (S), and (c) ZamynUud (Z). A half and full barb and a pennant indicate the wind speeds of 1,2, and $10 \mathrm{~m} / \mathrm{s}$, respectively.

\subsection{Extension of dust distribution}

At Sainshand, the cold front passed between 20 LST and 23 LST on 22 May 2013 as shown by the wind-direction change from the south to the northwest (Fig. 4b). The wind speed increased from $6 \mathrm{~m} / \mathrm{s}$ to $11 \mathrm{~m} / \mathrm{s}$ during the wind-direction change. A dust layer was observed near the ground from 22 LST on 22 to 02 LST on 23. After that, cold air advected over the ground with little dust. The depth of the cold air gradually increased from $1.0 \mathrm{~km}$ to $2.2 \mathrm{~km}$ until 07 LST on 23 . As with Dalanzadgad, the dust was elevated by the updraft of the warm air along the surface of the cold front. The dust formed a layer with a vertical thickness of about $2 \mathrm{~km}$. The distribution area of the dust was much larger than that at Dalanzadgad. The dust layer reached the free troposphere and mixed with clouds.

At Zamyn-Uud, the cold front passed between 02 LST and 05 LST on 23 as shown by the winddirection change from the southwest to the north (Fig. 4c). As with Sainshand, a dust layer was elevated by the updraft of the warm air along the surface of the cold front. The vertical thickness of the dust layer was about $1 \mathrm{~km}$ and smaller than that at Sainshand. The dust layer also reached the free troposphere and mixed with clouds.

Figure 5 illustrates an observational model of dust elevation and extension during the dust event. The dust distribution along the surface of the cold front was larger at Sainshand and Zamyn-Uud than that at Dalanzadgad. The dust layer was evolving from the atmospheric boundary layer to the free troposphere while moving across the desert with the cold front. This extension of the dust layer was caused by the updraft of the warm air in the cold-frontal system.

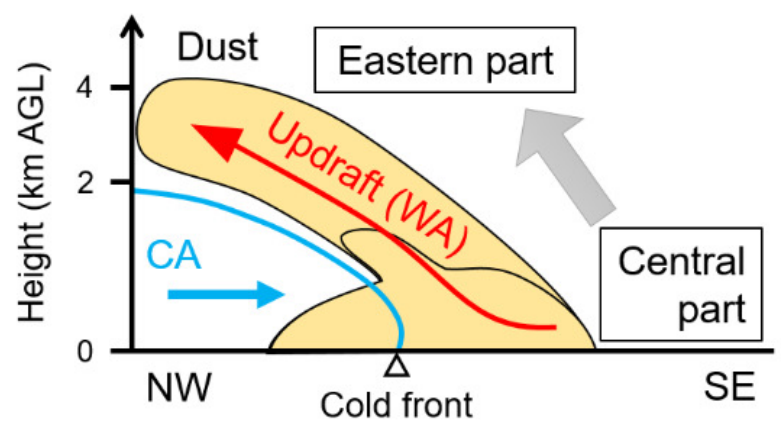

Figure 5 Observational model of dust elevation and extension in the Gobi Desert on 22-23 May 2013. CA and WA mean cold air and warm air, respectively. 


\section{CONCLUSIONS}

The Gobi Desert lidar network captured the evolution of a dust layer over the source region on 22-23 May 2013. The lidar network consists of a ceilometer and two AD-Net lidars in the central and eastern parts of the desert, respectively. The AD-Net lidars are $480 \mathrm{~km}$ and $600 \mathrm{~km}$ away from the ceilometer. During the dust event, a cold front associated with a low pressure moved southeastward across the desert with a speed of 30 $\mathrm{km} / \mathrm{h}$. The cold front generated strong northwest winds $(6-16 \mathrm{~m} / \mathrm{s})$, which raised dust from the ground and formed a dust layer in the atmospheric boundary layer. The dust layer was elevated along the surface of the cold front by an updraft of the warm air in the cold-frontal system. The updraft extended the dust layer to the free troposphere while the cold-frontal system was moving across the desert.

\section{ACKNOWLEDGEMENTS}

The present study is supported by Grant-in-Aid for Scientific Research from Japan Society for the Promotion of Science (JSPS) (No. 16H02703) and by JSPS Core-to-Core Program (B. Asia-Africa Science Platform).

\section{REFERENCES}

[1] Sun, J., Zhang, M., Liu, T., 2001: Spatial and temporal characteristics of dust storms in China and its surrounding regions, 1960-1999: Relations to source area and climate, J. Geophys. Res., 106, 10325-10333.

[2] Wu, J., Kurosaki, Y., Shinoda, M., Kai, K., 2016: Regional characteristics of recent dust occurrence and its controlling factors in East Asia, Sci. Online Lett. Atmos., 12, 187-191.

[3] Kai, K., Okada, Y., Uchino, O., Tabata, I., Nakamura, H., Takasugi, T., Nikaidou, Y., 1988: Lidar observation and numerical simulation of a Kosa (Asian Dust) over Tsukuba, Japan during the Spring of 1986, J. Meteor. Soc. Japan, 66, 457472.

[4] Uno, I., Eguchi, K., Yumimoto, K., Takemura, T., Shimizu, A., Uematsu, M., Liu, Z., Wang, Z.,
Hara, Y., Sugimoto, N., 2009: Asian dust transported one full circuit around the globe, Nature Geosci., 2, 557-560.

[5] Yumimoto, K., Eguchi, K., Uno, I., Takemura, T., Liu, Z., Shimizu, A., Sugimoto, N., 2009: An elevated large-scale dust veil from the Taklimakan Desert: Intercontinental transport and threedimensional structure as captured by CALIPSO and regional and global models, Atmos. Chem. Phys., 9, 8545-8558.

[6] Hara, Y., Yumimoto, K., Uno, I., Shimizu, A., Sugimoto, N., Liu, Z., Winker, D.M., 2009: Asian dust outflow in the PBL and free atmosphere retrieved by NASA CALIPSO and an assimilated dust transport model, Atmos. Chem. Phys., 9, 1227-1239.

[7] Alizadeh, C.O., Zawar-Reza, P., Sturman, A., 2012: Atmospheric forcing of the threedimensional distribution of dust particles over Australia: A case study, J. Geophys. Res., 117, D11206.

[8] Kawai, K., Kai, K., Jin, Y., Sugimoto, N., Batdorj, D., 2015: Dust event in the Gobi Desert on 22-23 May 2013: Transport of dust from the atmospheric boundary layer to the free troposphere by a cold front, Sci. Online Lett. Atmos., 11, 156-159.

[9] Sugimoto, N., Matsui, I., Shimizu, A., Nishizawa, T., Hara, Y., Xie, C., Uno, I., Yumimoto, K., Wang, Z., Yoon, S.C., 2008: Lidar network observations of tropospheric aerosols, Proc. SPIE, 7153, 71530A.

[10] Jin, Y., Kai, K., Kawai, K., Nagai, T., Sakai, T., Yamazaki, A., Uchiyama, A., Batdorj, D., Sugimoto, N., Nishizawa, N., 2015: Ceilometer calibration for retrieval of aerosol optical properties, J. Quant. Spectrosc. Radiat. Transfer, 153, 49-56.

[11] World Meteorological Organization (WMO), 1995: Manual on Codes, International Codes, Vol. I.1 (Annex II to WMO Technical Regulations) Part A-Alphanumeric Codes, WMO, Geneva, Switzerland, 492pp. 